\title{
PENINGKATAN KINERJA GURU DALAM MELAKSANAKAN PENILAIAN BERBASIS KELAS MELALUI SUPERVISI AKADEMIK KEPALA SEKOLAH DI SDN BEBIE
}

\author{
H. Muhadis \\ Kepala SDN Bebie Lombok Tengah, muhadisbebie@gmail.com
}

\section{INFO ARTIKEL}

Riwayat Artikel:

Diterima: 17-02-2018

Disetujui: 19-03-2018

\section{Kata Kunci:}

Kinerja Guru, Penilaian Berbasis Kelas, Supervisi Akademik.

\begin{abstract}
ABSTRAK
Abstrak: Tujuan diadakan Penelitian untuk mengetahui sejauh mana peningkatan kinerja guru dalam melaksanakan penilaian berbasis kelas melalui supervisi akademik Pengawas di SDN Bebie Kec.Praya Kab. Lombok Tengah tahun pelajaran 2016/2017. Hasil nilai 68,88 pada siklus l dengan prosentase kinerja guru secara kelompok/klasikal $37,5 \%$, dapat meningkat pada siklus 2 menjadi 80,63 dengan prosentase kinerja guru secara kelompok/klasikal 100\% sudah melebihi dari standar $85 \%$. disimpulkan bahwa penerapan supervisi akademik Kepala Sekolah dapat meningkatkan kinerja guru dengan ketuntasan kelompok/kalsikal mencapai $100 \%$, dengan demikian penerapan supervisi akademik Kepala Sekolah efektif meningkatkan kinerja guru dalam melaksanakan penilaian berbasis kelas di SDN Bebie Lombok Tengah.
\end{abstract}

\begin{abstract}
The purpose of this study to determine the extent to which improvements in teacher performance in implementing classroom-based assessment through supervision supervision supervision at SDN Bebie District Praya Central Lombok Tengah academic year 2016/2017. The result of score 68,88 in cycle 1 with the percentage of teacher performance in group / classical 37,5\%, can increase in cycle 2 to 80,63 with the percentage of teacher performance in group / classical 100\% already exceed from standard $85 \%$. it is concluded that the application of academic supervision of principal can improve teacher performance with group / classical completeness reach 100\%, thereby applying of principal academic supervision effectively improve teacher performance in carrying out class-based assessment at SDN Bebie Lombok Tengah.
\end{abstract}

\section{A. LATAR BELAKANG}

Pendidikan merupakan faktor yang penting bagi bangsa Indonesia karena pendidikan merupakan salah satu sarana untuk mencapai tujuan nasional. Menurut penjelasan umum UU No. 20 Tahun 2003 tentang Sistem Pendidikan Nasional, pendidikan adalah usaha sadar dan terencana untuk mewujudkan suasana belajar dan proses pembelajaran agar peserta didik secara aktif mengembangkan potensi dirinya untuk memiliki kekuatan spiritual, keagamaan, pengendalian diri, kepribadian, kecerdasan, akhlak mulia serta ketrampilan yang diperlukan dirinya, masyarakat, bangsa dan negara Peranan guru dalam proses pembelajaran adalah mengupayakan agar siswa dapat mencapai tujuan yang telah ditentukan. Untuk mencapai tujuan belajar, siswa melakukan kegiatan belajar dengan cara dan kemampuan masing-masing. Perbedaan itu akan membawa konsekuensi perolehan hasil belajar yang berbeda walaupun siswa mendapat pembelajaran yang sama. Untuk mengetahui keterlibatan siswa dalam proses pembelajaran, maka guru melaksanakan penilaian seperti yang tertuang dalam Undang-Undang No.20 tahun 2003, bahwa penilaian hasil belajar dilakukan peserta didik untuk memantau proses, kemajuan dan hasil belajar peserta didik secara berkesinambungan Pembelajaran adalah proses yang berkelanjutan, maka dalam rangka mencapai tujuan pembelajaran atau penugasan kompetensi tiap tahap pembelajaran perlu adanya suatu kegiatan yang sifatnya mengevaluasi yaitu penilaian pembelajaran dan apabila dalam tiap tahapan proses pembelajaran tersebut hasilnya kurang berhasil maka perlu dilakukan perbaikan. Kegagalan pembelajaran kemungkinan terjadi pada perencanaan pembelajaran, maupun hasil pembelajaran, maka kegiatan penilaian hendaknya mencakup penilaian perencanaan, proses dan hasil. Selama ini menurut pengamatan peneliti penilaian yang dilakukan oleh guru di sekolah umumnya penilaian hasil belajar saja, sementara penilaian perencanaan dan proses belajar belum dilakukan. Dengan demikian dapat diketahui bahwa penilaian terhadap proses pembelajaran menjadi tugas dan tanggung jawab guru, dalam upayanya meningkatkan kualitas pendidikan, khususnya kegiatan pembelajaran. Penentuan kualitas suatu lembaga pendidikan sangat ditentukan oleh penilai. Penilaian 
dilakukan untuk menilai proses pembelajaran, menilai prestasi siswa dalam suatu bidang pembelajaran, menilai kemajuan lembaga itu sendiri ( Yamin, 2007: 90). Untuk mengetahui tingkat pengetahuan tujuan pengajaran, penilaian memegang peranan yang sangat menentukan. Penilaian tingkat keberhasilan pendidikan dapat di ukur dengan baik. Salah satu prinsip penilaian hasil belajar adalah prinsip kontinuitas maksudnya bahwa penilaian dilakukan secara terus menerus terencana, terarah dan terprogram agar pihak evaluator (guru) dapat memperoleh gambaran tentang perkembangan siswa, untuk menentukan langkah-langkah pengambilan kebijaksanaan sehingga diharapkan tujuan dari pembelajaran dapat tercapai. Untuk mencapai tujuan pembelajaran tidak lepas dari kurikulum yang menjadi acuan dalam kegiatan pembelajaran kurikulum disini adalah kurikulum KTSP.

Dalam KTSP, penilaiannya dikenal dengan penilaian kelas yang didalamnnya terdapat proses pengumpulan pelaporan dan penggunaan informasi tentang belajar siswa yang diperoleh melalui pengukuran untuk menganalisis atau menjelaskan prestasi siswa dalam mengerjakan tugas-tugas yang terkait. Penilaian berbasis kelas adalah penilaian yang dilakukan selama dan setelah kegiatan belajar mengajar. Penilaian kelas dilakukan dalam bentuk pertanyaan lisan di kelas, kuis, ulangan harian, tugas kelompok, ulangan semester, ulangan kenaikan kelas, laporan kerja praktik atau laporan praktikum, responsi dan ujian akhir penilaian kelas. Penilaian kelas dilakukan guru untuk mengetahui kemajuan dan hasil belajar siswa, mendiagnosis kesulitan belajar, memberi umpan balik untuk proses perbaikan proses pembelajaran dan penentuan kenaikan kelas (Majid, 2005: 182) Sehubungan dengan diberlakukannya kurikulum KTSP apakah guru sudah melakukan penilaian berbasis kelas dengan efektif, hal tersebut menjadi motivasi penulis untuk melakukan penelitian dengan judul: "Peningkatan Kinerja Guru dalam Melaksanakan Penilaian Berbasis Kelas Melalui Supervisi Akademik Kepala Sekolah di SDN Bebie Kec. Praya Kab. Lombok Tengah Tahun Pelajaran 2016/2017".

\section{B. METODE PENELITIAN}

\section{Subyek Penelitian}

Subyek dalam penelitian ini adalah Guru SDN Bebie Kec. Praya Kab. Lombok Tengah tempat peneliti bertugas sebagai guru dan Kepala Sekolah tahun pelajaran 2016/2017. Jenis penelitian ini adalah Penelitian Tindakan Sekolah melalui penerapan supervisi akademik Kepala Sekolah. Jumlah guru yang menjadi obyek dalam penelitian, yaitu sebanyak 8 orang.

\section{Lokasi Penelitian}

a. Penelitian ini dilakukan pada guru SDN Bebie Kec. Praya Kab. Lombok Tengah tahun pelajaran 2016/2017.

b. Penelitian dilakukan pada guru baik yang PNS maupun Non PNS dengan dengan jumlah seluruhnya 8 orang.

\section{Rancangan Penelitian}

a. Tindakan dilaksanakan dalam 3 siklus

b. Kegiatan dilaksanakan dalam semester Genap tahun pelajaran 2016/2017.

c. Lama penelitian 6 pekan efektif dilaksanakan mulai tanggal 16 Januari sampai dengan 20 Februari 2017.

d. Dalam pelaksanaan tindakan, rancangan dilakukan dalam 3 siklus yang meliputi ; (a) perencanaan,(2) tindakan, (3) pengamatan, (4) refleksi.

4. Sumber Data dan Teknik Pengumpulan Data

b. Sumber Data: Sumber data dalam penelitian ini diperoleh data tentang peningkatan kinerja guru dalam melaksanakan penilaian berbasis kelas

c. Teknik Pengumpulan Data: Dalam Pengumpulan data menggunakan Observasi dan Tes.

\section{Indikator Keberhasilan}

Penelitian Tindakan Sekolahyang dilaksanakan dalam tiga siklus dianggap sudah berhasil apabila terjadi peningkatan kinerja guru dalam melaksanakan penilaian berbasis kelas mencapai $85 \%$ guru telah mencapai ketuntasan dengan nilai rata-rata 75 . Berarti telah memenuhi harapan ideal seperti yang disyaratkan dengan standar ideal minimal 75.

\section{Teknik Analisis Data}

Dalam analisis data teknik yang digunakan adalah ;

a. Kuantitatif

Analisis ini digunakan untuk menghitung besarnya peningkatan kinerja guru dalam melaksanakan penilaian berbasis kelas melalui supervisi akademik Kepala Sekolah dengan menggunakan persentase ( $\%)$.

b. Kualitatif

Teknik analisis ini digunakan untuk memberikan gambaran hasil penelitian secara ; reduksi data, sajian deskriptif, dan penarikan simpulan. 


\section{HASIL DAN PEMBAHASAN}

\section{Paparan Data dan Temuan Penelitian}

1. Perencanaan Tindakan

Penelitian ini menggunakan model pembinaan Kepala Sekolah melalui supervisi akademik.

Tujuan yang diharapkan pada pertemuan pertama dalam pembinaan Kepala Sekolah ini adalah peningkatan kinerja guru dalam melaksanakan penilaian berbasis kelas.

Agar tercapai tujuan di atas, peneliti yang bertindak sebagai pembimbing dengan melakukan langkah-langkah sebagai berikut:
a. Menyusun instrumen pembinaan
b. Menyusun Instrumen Monitoring
c. Sosialisasi kepada Guru
d. Melaksanakan tindakan dalam keKepala Sekolahan
e. Melakukan refleksi
f. Menyusun strategi pembinaan pada siklus ke dua berdasar refleksi siklus pertama
g. Melaksanakan pembinaan pada siklus kedua
h. Melakukan Observasi
i. Melakukan refleksi pada siklus kedua
j. Menyusun strategi pembinaan pada siklus ketiga berdasar refleksi siklus kedua
k. Melaksanakan pembinaan pada siklus ketiga
l. Melakukan Observasi
m. Melakukan refleksi pada siklus ketiga
n. Menyusun laporan

2. Pelaksanaan Tindakan dan Pengamatan

Pelaksanaan tindakan dalam penelitian dilakukan 3 siklus yang terdiri dari tiga kali pertemuan.

Waktu yang digunakan setiap kali pertemuan adalah 2 x 35 menit. Pertemuan pertama dilaksanakan pada tanggal 16 s.d 23 Januari 2017 dan pertemuan kedua pada tanggal 30 Januari s.d 06 Februari 2017 dan pertemuan ke tiga 13 s.d 20 Februari 2017. Penelitian Tindakan Sekolahini dilaksanakan sesuai dengan prosedur jadwal pembinaan dan skenario Sekolahdan dilaksanakan pada saat proses belajar mengajar berlangsung. Berikut hasil pembinaan Kepala Sekolah melalui supervisi akademik per siklus sebagai berikut :

SIKLUS 1

a. Tahap Perencanaan

Pada tahap ini peneliti mempersiapkan perangkat pembinaan yang terdiri dari jadwal tindakan, soal tes formatif 1 dan alatalat pembinaan lain yang mendukung. Selain itu juga dipersiapkan lembar observasi peningkatan kinerja guru melalui supervisi akademik.

b. Tahap Kegiatan dan Pelaksanaan

Pelaksanaan kegiatan pembinaan untuk siklus I dilaksanakan pada tanggal 16 s.d 23
Januari 2017 di SDN Bebie Kec. PrayaKab. Lombok Tengah tahun pelajaran 2016/2017. Dalam hal ini peneliti bertindak sebagai Kepala Sekolah. Adapun proses pembinaan mengacu pada jadwal pembinaan yang telah dipersiapkan.

Pengamatan (observasi) dilaksanakan bersamaan dengan pelaksanaan pembinaan di sekolah. Pada akhir proses pembinaan guru diberi tes formatif I dengan tujuan untuk mengetahui tingkat keberhasilan Kepala Sekolah dalam meningkatkan kinerjanya sesuai dengan yang telah dilakukan. Adapun data hasil penelitian pada siklus I adalah seperti pada tabel berikut:

TABEL 1

TABEL DISTRIBUSI NILAI TES PADA SIKLUS

\begin{tabular}{|c|c|c|c|c|}
\hline \multirow{2}{*}{ No } & \multirow{2}{*}{ Nama } & \multirow{2}{*}{$\begin{array}{l}\text { Sko } \\
\text { r }\end{array}$} & \multicolumn{2}{|c|}{ Keterangan } \\
\hline & & & $\mathrm{T}$ & $\mathrm{T} \mathrm{T}$ \\
\hline 1 & Muhamad Luan & 76 & $\sqrt{ }$ & \\
\hline 2 & H. M. Syukri & 60 & & $\sqrt{ }$ \\
\hline 3 & Izhar,S.PdI & 80 & $\sqrt{ }$ & \\
\hline 4 & Muhsin,A.Ma & 70 & & $\sqrt{ }$ \\
\hline 5 & Lalu Hanan & 65 & & $\sqrt{ }$ \\
\hline 6 & Lisa Januarni & 70 & & $\sqrt{ }$ \\
\hline 7 & Fakhrudin & 70 & & $\sqrt{ }$ \\
\hline 8 & Nur Kuratul Aen & 75 & $\sqrt{ }$ & \\
\hline \multicolumn{2}{|c|}{ Jumlah Total } & 566 & - & - \\
\hline \multicolumn{2}{|c|}{ Skor Maksimum Individu } & 100 & - & - \\
\hline \multicolumn{2}{|c|}{$\begin{array}{l}\text { Skormaksimum } \\
\text { Kelompok Guru }\end{array}$} & 800 & - & - \\
\hline
\end{tabular}

\section{Keterangan :}

Jumlah Guru yang tuntas = 3 Orang

Jumlah Guru yang belum tuntas $=5$ Orang Kelompok Guru : belum tuntas

Dari tabel di atas dapat dijelaskan bahwa dengan pembinaan yang dilakukan oleh Kepala Sekolah melalui supervisi akademik diperoleh nilai rata-rata peningkatan kinerja guru adalah 70,75 \%. Hasil tersebut menunjukkan bahwa pada siklus pertama secara kelompok guru belum meningkat kinerjanya, karena yang memperoleh nilai $\geq$ 75 hanya sebesar $37,5 \%$ atau ada 3 orang guru dari 8 orang sudah tuntas, hasil ini lebih kecil dari persentase ketuntasan yang dikehendaki yaitu sebesar $85 \%$. Hal ini disebabkan karena banyak guru yang belum memahami materi sehingga mereka merasa baru dengan tugas.

c. Refleksi

Dalam pelaksanaan kegiatan pembinaan diperoleh informasi dari hasil pengamatan sebagai berikut: 
(1) Kepala Sekolah masih kurang teliti dalam melakukan pembinaan di sekolah

(2) Kepala Sekolah masih kurang baik dalam pemanfaat waktu

(3) Kepala Sekolah masih kurang konsentrasi dalam melakukan pembinaan, karena ada tugas lain yang harus dikerjakan.

d. Revisi Rancangan

Pelaksanaan kegiatan pembinaan pada siklus I ini masih terdapat kekurangan, sehingga perlu adanya revisi untuk dilakukan pada siklus berikutnya.

1) Kepala Sekolah perlu lebih terampil dalam memotivasi guru dan lebih jelas dalam menyampaikan tujuan pembinaan. Di mana guru diajak untuk terlibat langsung dalam setiap kegiatan yang dilakukan.

2) Kepala Sekolah perlu mendistribusikan waktu secara baik dengan menambahkan informasi-informasi yang dirasa perlu dan memberi catatan

3) Kepala Sekolah harus lebih terampil dan bersemangat dalam memotivasi guru sehingga kinerjanya lebih meningkat.

\section{SIKLUS II}

1. Tahap perencanaan

Pada tahap ini peneliti mempersiapkan perangkat pembinaan yang terdiri dari jadwal pembinaan 2, soal tes formatif II dan alat-alat Sekolahlain yang mendukung.

2. Tahap kegiatan dan pelaksanaan

Pelaksanaan kegiatan pembinaan supervisi akademik untuk siklus II dilaksanakan pada tanggal 30 Januari s.d 06 Februari 2017 di SDN Bebie Kec. PrayaKab. Lombok Tengah tahun pelajaran 2016/2017. Dalam hal ini peneliti bertindak sebagai Kepala Sekolah. Adapun proses pembinaan mengacu pada jadwal pembinaan dengan memperhatikan revisi pada siklus I, sehingga kesalahan atau kekurangan pada siklus I tidak terulang lagi pada siklus II. Penelitian Tindakan Sekolahini dilaksanakan pada saat proses belajar mengajar berlangsung.

Pada akhir proses pembinaan guru diberi tes formatif II dengan tujuan untuk mengetahui tingkat keberhasilan Kepala Sekolah dalam meningkatkan kinerjanya. Instrumen yang digunakan adalah tes formatif II. Adapun data hasil penelitian pada siklus II adalah sebagai berikut
TABEL 2

TABEL DISTRIBUSI NILAI TES PADA SIKLUS II

\begin{tabular}{|c|l|c|c|l|}
\hline \multirow{2}{*}{ No } & \multirow{2}{*}{ Nama } & \multirow{2}{*}{ Skor } & \multicolumn{2}{|c|}{ Keterangan } \\
\cline { 4 - 6 } & & & T & TT \\
\hline 1 & Muhamad Luan & 80 & $\sqrt{ }$ & \\
\hline 2 & H. M. Syukri & 76 & $\sqrt{ }$ & \\
\hline 3 & Izhar,S.PdI & 80 & $\sqrt{ }$ & \\
\hline 4 & Muhsin,A.Ma & 74 & & $\sqrt{ }$ \\
\hline 5 & Lalu Hanan & 80 & $\sqrt{ }$ & \\
\hline 6 & Lisa Januarni & 77 & $\sqrt{ }$ & \\
\hline 7 & Fakhrudin & 73 & & $\sqrt{ }$ \\
\hline 8 & Nur Kuratul Aen & 75 & $\sqrt{ }$ & \\
\hline Jumlah Total & 615 & - & - \\
\hline \multicolumn{2}{|l|}{ Skor Maksimum Individu } & 100 & - & - \\
\hline $\begin{array}{l}\text { Skor Maksimum } \\
\text { Kelompok Guru }\end{array}$ & 800 & - & - \\
\hline
\end{tabular}

Keterangan:

Jumlah Guru yang tuntas $=6$ Orang

Jumlah Guru yang belum tuntas $=3$ Orang

Kelompok Guru : belum tuntas.

Dari tabel di atas diperoleh nilai rata-rata peningkatan kinerja guru adalah 76,88 sudah lebih dari standar 75 tetapi baru mencapai $75 \%$ atau kurang dari $85 \%$ yang dipersyaratkan yaitu 6 orang dari 8 orang guru yang sudah tuntas dalam meningkatkan kinerjanya. Hasil ini menunjukkan bahwa pada siklus II ini peningkatan guru telah mengalami peningkatan sedikit lebih baik dari siklus I. Adanya peningkatan kinerja guru ini karena setelah Kepala Sekolah telah menginformasikan bahwa setiap akhir pembinaan diadakan penilaian sehingga pada pertemuan berikutnya guru lebih termotivasi untuk meningkatkan kinerjanya. Selain itu guru juga sudah mulai mengerti apa yang dimaksudkan dan diinginkan oleh Kepala Sekolah dalam melakukan pembinaan supervisi akademik.

3. Refleksi

Dalam pelaksanaan pembinaan diperoleh informasi dari hasil pengamatan sebagai berikut:

a. Memotivasi guru

b. Membimbing guru dalam menyusun rencana kerja guru merumuskan kesimpulan/menemukan konsep

c. Pengelolaan waktu

4. Revisi Pelaksanaaan

Pelaksanaan pembinaan pada siklus II ini masih terdapat kekurangan-kekurangan. Maka perlu adanya revisi untuk dilaksanakan pada siklus III antara lain:

a. Kepala Sekolah dalam memberikan pembinaan kepada guru hendaknya dapat 
membuat guru termotivasi dalam membuat program dan rencana sekolah.

b. Kepala Sekolah harus lebih dekat dengan guru sehingga tidak ada perasaan takut/malu dalam diri guru terutama dalam bertanya tentang masalah yang dihadapi oleh sekolah.

c. Kepala Sekolah harus lebih sabar dalam melakukan pembinan kepada guru terutama dalam merumuskan kesimpulan/menemukan konsep.

d. Kepala Sekolah harus mendistribusikan waktu secara baik sehingga kegiatan pembinaan dapat berjalan efektif sesuai dengan yang diharapkan.

\section{SIKLUS III}

1. Tahap Perencanaan

Pada tahap ini peneliti mempersiapkan perangkat pembinaan yang terdiri dari jadwal pembinaan 3 , soal tes formatif 3 dan alat-alat pembinaan lainnya yang mendukung.

2. Tahap kegiatan dan pengamatan

Pelaksanaan pembinaan untuk siklus III dilaksanakan pada tanggal 13 s.d 20 Februari 2017 di SDN Bebie Kec. PrayaKab. Lombok Tengah tahun pelajaran 2016/2017 dengan jumlah 23 orang guru. Dalam hal ini peneliti bertindak sebagai Kepala Sekolah. Adapun proses pembinaaan mengacu pada jadwal pembinaan dengan memperhatikan revisi pada siklus II, sehingga kesalahan atau kekurangan pada siklus II tidak terulang lagi pada siklus III. Pengamatan (observasi) dilaksanakan bersamaan dengan pelaksanaan proses belajar mengajar di sekolah.

Pada akhir proses pembinaan guru diberi tes formatif III dengan tujuan untuk mengetahui tingkat keberhasilan guru dalam meningkatkan kinerjanya yang telah dilakukan. Instrumen yang digunakan adalah tes formatif III. Adapun data hasil penelitian pada siklus III adalah sebagai berikut :

TABEL 3

TABEL DISTRIBUSI NILAI TES PADA SIKLUS III

\begin{tabular}{|c|l|c|c|c|}
\hline \multirow{2}{*}{ No } & \multirow{2}{*}{ Nama } & \multirow{2}{*}{ Skor } & \multicolumn{2}{|c|}{$\begin{array}{c}\text { Keteran } \\
\text { gan }\end{array}$} \\
\cline { 4 - 6 } & & & T & TT \\
\hline 1 & Muhamad Luan & 90 & $\sqrt{ }$ & \\
\hline 2 & H. M. Syukri & 80 & $\sqrt{ }$ & \\
\hline 3 & Izhar,S.PdI & 83 & $\sqrt{ }$ & \\
\hline 4 & Muhsin,A.Ma & 80 & $\sqrt{ }$ & \\
\hline 5 & Lalu Hanan & 80 & $\sqrt{ }$ & \\
\hline 6 & Lisa Januarni & 79 & $\sqrt{ }$ & \\
\hline 7 & Fakhrudin & 74 & & $\sqrt{ }$ \\
\hline
\end{tabular}

\begin{tabular}{|l|l|l|l|l|}
\hline 8 & Nur Kuratul Aen & 75 & $\sqrt{ }$ & \\
\hline Jumlah Total & 641 & - & - \\
\hline Skor Maksimum Individu & 100 & - & - \\
\hline $\begin{array}{l}\text { Skor Maksimum Kelompok } \\
\text { Kelompok Guru }\end{array}$ & 800 & - & - \\
\hline
\end{tabular}

Keterangan:

Jumlah Guru yang tuntas $=7$ orang

Jumlah Guru yang belum tuntas $=1$ Orang

Kelompok Guru = Sudah tuntas

Berdasarkan tabel di atas diperoleh nilai ratarata tes formatif sebesar 80,13 dianggap tuntas karena $>75$ dan 7 orang dari 8 atau $87,5 \%$ guru sudah meningkatkan kinerjannya ( termasuk kategori tuntas ). Hasil pada siklus III ini mengalami peningkatan lebih baik dari siklus II. Adanya peningkatan hasil pembinaan pada siklus III ini dipengaruhi oleh adanya peningkatan kemampuan Kepala Sekolah dalam menerapkan pembinaan melalui supervisi akademik sehingga guru menjadi lebih memahami tugasnya sehingga dapat meningkatkan kinerjanya. Di samping itu ketuntasan ini juga dipengaruhi oleh kerja sama dari guru dengan Kepala Sekolah dalam merencanakan program kerja sekolahnya masing-masing.

3. Refleksi

Pada tahap ini dikaji apa yang telah terlaksana dengan baik maupun yang masih kurang baik dalam proses pembinaan melalui supervisi akademik Dari data-data yang telah diperoleh dapat diuraikan sebagai berikut:

a. Selama proses pembinaan Kepala Sekolah telah melaksanakan semua pembinaan dengan baik. Meskipun ada beberapa aspek yang belum sempurna, tetapi persentase pelaksanaannya untuk masing-masing aspek cukup besar.

b. Berdasarkan data hasil pengamatan diketahui bahwa guru aktif selama proses pembinaan berlangsung.

c. Kekurangan pada siklus-siklus sebelumnya sudah mengalami perbaikan dan peningkatan sehingga menjadi lebih baik.

d. Hasil pembinaan guru oleh Kepala Sekolah melalui supervisi akademik pada siklus III mencapai ketuntasan.

4. Revisi Pelaksanaan

Pada siklus III Kepala Sekolah telah melaksanakan pembinaan dengan baik dan dilihat dari peningkatan kinerja guru pelaksanaan pembinaan sudah berjalan dengan baik. Maka tidak diperlukan revisi terlalu banyak, tetapi yang perlu diperhatikan untuk tindakan selanjutnya adalah 
memaksimalkan dan mempertahankan apa yang telah ada dengan tujuan agar pada pelaksanaan pembinaan selanjutnya baik melalui supervisi akademik Kepala Sekolah dapat meningkatkan kinerja guru sehingga tujuan pembinaan sebagai upaya meningkatkan mutu pendidikan dapat tercapai.

\section{Analisis Hasil Kegiatan}

Setelah dilakukan tindakan pada siklus 1 , siklus 2 dan siklus 3 menunjukkan hasil sebagai berikut:

TABEL 5

ANALISIS HASIL TES TENTANG PENINGKATAN KINERJA GURU

\begin{tabular}{|c|l|l|l|c|}
\hline No & \multicolumn{1}{|c|}{ Nama } & Sebelum & Setelah & $\begin{array}{c}\text { Setelah } \\
\text { Tindakan }\end{array}$ \\
\hline 1 & Muhamad Luan & 76 & 80 & 90 \\
\hline 2 & H. M. Syukri & 60 & 76 & 80 \\
\hline 3 & Izhar,S.PdI & 80 & 80 & 83 \\
\hline 4 & Muhsin,A.Ma & 70 & 74 & 80 \\
\hline 5 & Lalu Hanan & 65 & 80 & 80 \\
\hline 6 & Lisa Januarni & 70 & 77 & 79 \\
\hline 7 & Fakhrudin & 70 & 73 & 74 \\
\hline 8 & $\begin{array}{l}\text { Nur Kuratul } \\
\text { Aen }\end{array}$ & 75 & 75 & 75 \\
\hline Jumlah Total & 566 & 615 & 641 \\
\hline $\begin{array}{l}\text { Skor Maksimum } \\
\text { Individu }\end{array}$ & 100 & 100 & 100 \\
\hline $\begin{array}{l}\text { Skor Maksimum } \\
\text { Kelas }\end{array}$ & 800 & 800 & 800 \\
\hline \multicolumn{2}{|l|}{ Skor Nilai } & 70,75 & 76,88 & \\
\hline
\end{tabular}

\section{Analisis Data Deskriptif Kuantitatif}

1. Pencapaian peningkatan kinerja guru dalam melaksanakan penilaian berbasis kelas siklus I sebesar 70,75, siklus 2 sebesar 76,88 dan siklus 3 sebesar 80,13

2. Prosentase Rata-rata kinerja guru dalam kelompok sebelum diberi pembinaan 70,75\% ( siklus I ), naik menjadi $75 \%$ ( siklus II ), dan siklus III naik menjadi 87,5 \%.

\section{Refleksi dan Temuan}

Berdasarkan pelaksanaan pembinaan yang telah dilakukan Kepala Sekolah kepada guru melalui supervisi akademik maka hasil observasi nilai, dapat dikatakan sebagai berikut :

1. Pertemuan pertama kegiatan pembinaan belum berhasil karena dalam pembinaan Kepala Sekolah masih terlihat guru belum begitu antusias karena mereka masih menganggap pembinaan Kepala Sekolah tersebut merupakan tugas baru yang diembannya ;

2. Pembinaan yang dilakukan melalui supervisi akademik Kepala Sekolah, dalam hal peningkatan kinerja guru belum tampak, sehingga hasil yang dicapai tidak tuntas.

3. Mungkin karena proses pembinaan yang menggunakan pembinaan melalui supervisi akademik Kepala Sekolah yang baru mereka laksanakan sehingga guru merasa kaku dalam menerapkannya.

4. Akan tetapi setelah dijelaskan, mereka bisa mengerti dan buktinya pada pertemuan kedua dan ketiga proses pembinaan Kepala Sekolah berjalan baik, semua Kepala Sekolah aktif dan lebih-lebih setelah ada rubrik penilaian proses, semua Kepala Sekolah antusias untuk mengikutinya.

\section{TEMUAN ATAU DISKUSI}

1. Ketuntasan Hasil Pembinaan Kinerja Guru

Melalui hasil penelitian ini menunjukkan bahwa pembinaan melalui supervisi akademik Kepala Sekolah memiliki dampak positif meningkatkan kinerja guru dalam melaksanakan penilaian berbasis kelas, hal ini dapat dilihat dari semakin mantapnya pemahaman guru terhadap pembinaan yang disampaikan Kepala Sekolah ( kinerja guru meningkat dari siklus I, II, dan III ) yaitu masing-masing $67,17 \% ; 77,17 \% ; 85,86 \%$. Pada siklus III kinerja guru secara kelompok mencapai 87,5\%.

Kemampuan Kepala Sekolah dalam Meningkatkan Kinerja Guru

Berdasarkan analisis data, diperoleh aktivitas guru dalam meningkatkan kinerjanya dalam setiap siklus mengalami peningkatan. Hal ini berdampak positif terhadap kinerja guru dalam melaksanakan penilaian berbasis kelas yaitu dapat ditunjukkan dengan meningkatnya nilai rata-rata guru pada setiap siklus yang terus mengalami peningkatan.

2. Aktivitas Kepala Sekolah dan Guru dalam Pembinaan melalui Supervisi Akademik ;

Berdasarkan analisis data, diperoleh aktivitas Kepala Sekolah dan guru yang paling dominan dalam kegiatan supervisi akademik adalah bekerja dengan menggunakan alat/media, mendengarkan / memperhatikan penjelasan Kepala Sekolah, dan diskusi antar guru dan Kepala Sekolah. Jadi dapat dikatakan bahwa aktivitas guru dapat dikategorikan aktif.

Sedangkan untuk aktivitas Kepala Sekolah selama pembinaan telah melaksanakan langkah-langkah metode pembinaan melalui supervisi akademik dengan baik. Hal ini terlihat dari aktivitas guru yang muncul di antaranya aktivitas membuat dan merencanakan program sekolah, melaksanakan, memberi umpan balik/evaluasi/tanya jawab di mana persentase untuk aktivitas di atas cukup besar. 
Berdasarkan hasil penelitian di atas, peningkatan kinerja guru dalam melaksanakan penilaian berbasis kelas melalui supervisi akademik Kepala Sekolah hasilnya sangat baik. Hal itu tampak pada pertemuan dari 8 orang guru yang ada pada saat penelitian ini dilakukan nilai rata rata mencapai ; 70,75 meningkat menjadi 76,88 dan pada siklus 3 meningkat menjadi 80,13 .

Dari analisis data di atas bahwa pembinaan kinerja guru dalam melaksanakan penilaian berbasis kelas melalui supervisi akademik Kepala Sekolah efektif diterapkan, yang berarti proses pembinaan Kepala Sekolah lebih berhasil dan dapat meningkatkan kinerja guru khususnya guru SDN Bebie Kec. Praya Kab. Lombok Tengah, oleh karena itu diharapkan kepada para Kepala Sekolah dapat melaksanakan pembinaan melalui supervisi akademik secara berkelanjutan.

\section{E. SIMPULAN DAN SARAN}

Berdasarkan analisis hasil penelitian dan diskusi dapat disimpulkan sebagai berikut :

1. Pembinaan Kepala Sekolah upaya meningkatkan kinerja guru dalam melaksanakan penilaian berbasis kelas melalui supervisi akademik Kepala Sekolah menunjukan peningkatan pada tiap-tiap putaran (Siklus ).

2. Aktivitas dalam kegiatan pembinaan menunjukan bahwa seluruh guru dapat meningkatkan kinerjanya dengan baik dalam setiap aspek.

3. Peningkatan kinerja guru dalam melaksanakan penilaian berbasis kelas melalui supervisi akademik Kepala Sekolah ini menunjukan peningkatan pada tiap-tiap putarannya.

Aktivitas Kepala Sekolah menunjukan bahwa kegiatan pembinaan melalui supervisi akademik Kepala Sekolah bermanfaat dan dapat membantu guru untuk lebih mudah memahami

\section{UCAPAN TERIMA KASIH}

Dengan penuh rasa hormat, saya ucapkan teimakasih kepada:

1. Kepala Dinas Pendidikan yang telah memfasilitasi, mengizinkan penulis untk mengadakan penelitian hingga dapat terlaksana dengan baik.

2. Guru-guru yang telah memberi dukungan baik secara moral maupun tindakan langsung dalam pelaksanaan penelitian ini.

\section{DAFTAR RUJUKAN}

Arikunto, Suharsimi. 2007. Penelitian Tindakan Kepala Sekolahan. Jakarta: PT Bumi Aksara.

Bellon, J. J., \& Bellon,E. C. 1982. Classroom Supervision and Instructional Improvement : A Synergetic Process (2nd ed.). Dubuque, IA: Kendall/Hunt.

Cogan, Morris. 1973. Academic Supervision. Boston: Holt, Reinhart and Winston.

Costa, A. L., \& Garmston, R. J. 1994. Cognitive Coaching: A Foundation for Renaissance Schools. Norwood, MA: Christopher-Gordon.

Depdikbud. 1984. Program Akta Mengajar V-B Komponen Dasar Kependidikan: Penilaian Program Pendidikan. Jakarta: Universitas Terbuka.

Glickman, C. D. 1990. Supervision of Instruction: A Developmet Approach (2nd ed.). Boston: Allyn and Bacon.

Hamalik, Oemar. 2002. Psikologi Belajar dan Mengajar. Bandung: Sinar Baru.

Harris, B. M. 1975. Supervisory Behavior In Education (2nded.). Englewood Cliffs, NJ: Prentice-Hall.

Majid, 2005. Perencanaan Pembelajaran dan Mengembangkan Standar Kompetensi Guru. Bandung: PT Remaja RoSDNa Karya.

Nanang Fattah. 1996. Landasan Manajemen Pendidikan. Bandung: Remaja RoSDNakarya.

Pajak, E. F. 1993. Approaches To Academic Supervision: Alternatives For Improving Instruction. Norwood, MA: Christopher-Gordon.

Sergiovanni, T. J., \& Starratt, R. J. 1998. Supervision: A ReDefinition (6th ed.). Boston: McGraw-Hill.

Sullivan, S., \& Glanz, J. 2000. Alternative Approaches To Supervision: Cases from the field. Journal of Curriculum and Supervision, 15(3), 212-235.

Dedi. 1998. Mengangkat Citra dan Martabat Guru. Yogyakarta: Adicita Karya Nusantara.

Unruh, A., \& Turner, H. E. 1970. Supervision For Change and Innovation. Boston: Houghton-Mifflin.

Widyastono, Herry. 1999. Kinerja Guru. Jurnal Pendidikan dan Kebudayaan No 20 tahun ke-5, Desember.

Yamin, Martinis. 2007. Profesionalisasi Guru \& Implementasi KTSP. Jakarta: Gaung Persada Press. 